\title{
Social organisation of the northern giant mouse lemur Mirza zaza in Sahamalaza, north western Madagascar, inferred from nest group composition and genetic relatedness
}

\author{
E. Johanna Rode ${ }^{1,2}$, K. Anne-Isola Nekaris ${ }^{2}$, Matthias Markolf ${ }^{3}$, Susanne Schliehe-Diecks ${ }^{3}$, Melanie Seiler ${ }^{1,4}$, Ute \\ Radespiel $^{5}$, Christoph Schwitzer ${ }^{1,6}$ \\ ${ }^{1}$ Bristol Conservation and Science Foundation, clo Bristol Zoo Gardens, Clifton, Bristol BS8 3HA, UK \\ ${ }^{2}$ Nocturnal Primate Research Group, School of Social Sciences and Law, Oxford Brookes University, Headington \\ Campus, Gipsy Lane, OX3 OBP, UK \\ ${ }^{3}$ German Primate Center, Kellner Weg 4, 37077 Göttingen, Germany \\ ${ }^{4}$ School of Biological Sciences, University of Bristol, Woodland Road, Bristol BS8 1UG, UK \\ ${ }^{5}$ Institute of Zoology, University of Veterinary Medicine Hannover, Buenteweg 2, 30559 Hannover, Germany \\ ${ }^{6}$ E-mail: cschwitzer@bcsf.org.uk
}

Key words: conservation, fragmentation, genetic diversity, nest utilisation, sleeping site, small population genetics

\begin{abstract}
Shelters such as leaf nests, tree holes or vegetation tangles play a crucial role in the life of many nocturnal mammals. While information about characteristics and availability of these resources may help in conservation planning, nest use gives an indication about a species' social organisation. The northern giant mouse lemur (Mirza zaza) is threatened by habitat loss within its restricted range. Our aim was to examine nest site preferences of M. zaza and to explore the species' social organisation by examining sleeping site aggregation size and genetic relatedness within and between such aggregations. In the Ankarafa Forest inside Sahamalaza - Iles Radama National Park, northwestern Madagascar, we radio-tagged five male and three female $M$. zaza and followed them for 2.5 months during the dry season. We identified sleeping trees and observed animals during emergence in the evening and return in the morning. We compared sleeping trees and microhabitats around nest sites to trees and habitat used during nightly activity and to random sites. We found that nests were well covered by canopy, even during the dry season, and were located near the tree trunk a few meters below the tree top. Nest sites were characterised by large $(>30 \mathrm{~cm} \mathrm{DBH})$ and tall trees $(>16 \mathrm{~m})$ with many lianas. Up to four animals shared one to three group-exclusive nests for up to 50 days. Two of the nest groups included two and three males with fully developed testes. Relatedness data revealed that the adult males sharing nests were either unrelated or closely related. These data suggest that M. zaza is sleeping in social nest groups including multiple males, which is unusual among nocturnal strepsirrhines. Apart from protecting suitable sleeping trees and discouraging selective logging of large trees, we recommend conducting further studies on the species' social organisation throughout an entire season.
\end{abstract}

\section{Contents}

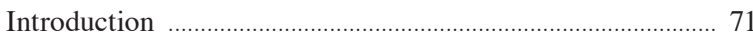

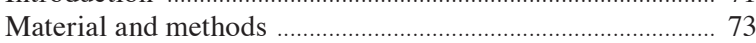

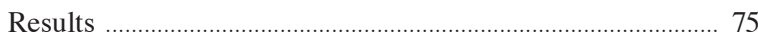

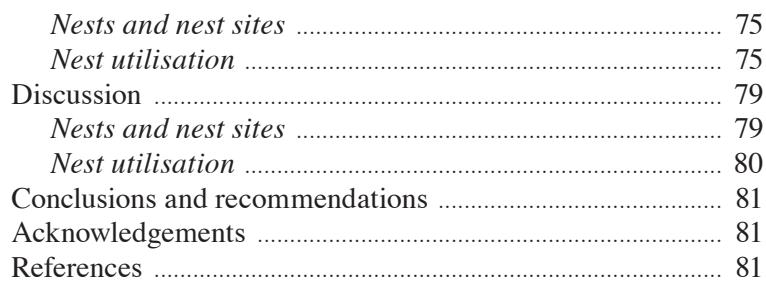

\section{Introduction}

Security offered by shelters is an important aspect in the survival and reproduction of many small mammals, including strepsirrhine primates (Terborgh and Janson, 1986; Anderson, 1998; Kappeler, 1998). Types of shelters include tree holes or cavities, dense vegetation tangles and self-constructed or abandoned leaf nests (Bearder et al., 2003). Shelters provide protection against predators, especially when raising young, and protect against environmental conditions such as temperature changes (Aquino and Encarnación, 1986; Anderson, 1998; Kappeler, 1998; Perret, 1998; Schmid, 1998; Biebouw et al., 2009). Although tree holes are generally regarded as high-quality shelters (Radespiel et al., 1998; Schmid, 1998), constructing leaf nests has a high adaptive potential due to independence from pre-formed tree cavities and possible immediate and flexible responses to environmental changes (Thorén et al., 2010). While some taxa like diurnal ruffed lemurs (Varecia variegata (Kerr, 1792)) only use nests in the breeding season to hide their altricial infants (Kappeler, 1998), many adult nocturnal strepsirrhines spend the day in leaf nests, including Galagoides, Galago and Otolemur (Bearder and Doyle, 1974; 
Bearder et al., 2003), Microcebus ravelobensis Zimmermann et al., 1998 (Weidt et al., 2004; Thorén et al., 2010), M. murinus (J. F. Miller, 1777) (Radespiel et al., 1998), Mirza coquereli (A. Grandidier, 1867) (Sarikaya and Kappeler, 1997), Cheirogaleus major É. Geoffroy, 1812 (Wright and Martin, 1995) and Daubentonia madagascariensis (Gmelin, 1788) (Sterling 1993; Ancrenaz et al., 1994). Type and location of nests probably have a crucial impact on the survival and reproduction of nest-using species (Wells et al., 2006). Information about nests and sleeping trees could assist in conservation planning, for example to inform restoration of habitat or develop indirect census techniques (Plumptre and Reynolds, 1997; Blom et al., 2001; Johnson et al., 2004).

Mirza zaza Kappeler and Roos in Kappeler et al., 2005 is one of at least eight nocturnal lemur species in Madagascar that uses arboreal leaf nests as shelters during the day (Kappeler, 1998; Kappeler et al., 2005; Thorén et al., 2010). The species is classified as Vulnerable on the IUCN Red List due to its restricted and highly fragmented distribution (Rode et al., 2011). Because $M$. zaza occurs in only one protected area and due to on-going threats to remaining and fragmented forests where it occurs (Schwitzer and Lork, 2004; Schwitzer et al., 2007), information on its ecological needs is urgently required to design conservation measures.

In contrast to $M$. coquereli, where males and females have never been observed to share nests (Kappeler, 1997), M. zaza on the Ambato Peninsula, near Ambanja, was observed to sleep in self-constructed, spherical leaf nests with two to eight individuals including several adult males (Kappeler et al., 2005). Large nests can become unstable and disintegrate with time (Lindenmayer et al., 2008), which sets an upper limit for nest size. Wells et al. (2006) have shown that support and location are important conditions for a good nest; stability and texture of branches must be appropriate, and materials for construction must be available. The height and position of nests have an impact on thermoregulation including exposure to sun and rain or humidity (Bearder et al., 2003). The nests of $M$. coquereli in Kirindy were built a few meters below the top of trees of the genus Securinega (family Euphorbiaceae) (Sarikaya and Kappeler, 1997) while Pages (1980) reported heights of 2-10 $\mathrm{m}$ in trees that did not shed their leaves (Euphorbiaceae) and were covered in lianas.

Sleeping in nest groups can have energetic advantages. Social constraints and the need for some small animals to enter torpor can limit the maximum number of animals sleeping together, as has been shown for Microcebus murinus, where such constraints limit group size to two to four animals (Perret, 1998). Nest associations can give an indication about the social organization and mating system of the species (Kappeler and van Schaik, 2002). Most nocturnal strepsirrhines sleep in small groups including female kin and offspring (Nash and Harcourt, 1986; Radespiel, 2006), with several males sleeping rarely together (Pullen et al., 2000; Bearder et al., 2003; Eberle and Kappeler, 2006; but see Loris lydekkerianus lydekkerianus Cabrera, 1908; Nekaris, 2003). Morphological and behavioural data suggest a promiscuous mating system for Mirza zaza (Kappeler et al. 2005; Rode, 2010); information about nest use could sharpen this picture.

With information about the rarity of $M$. zaza becoming increasingly available, we aim to answer two questions regarding their nesting behaviour in relation to potential habitat management for their conservation.

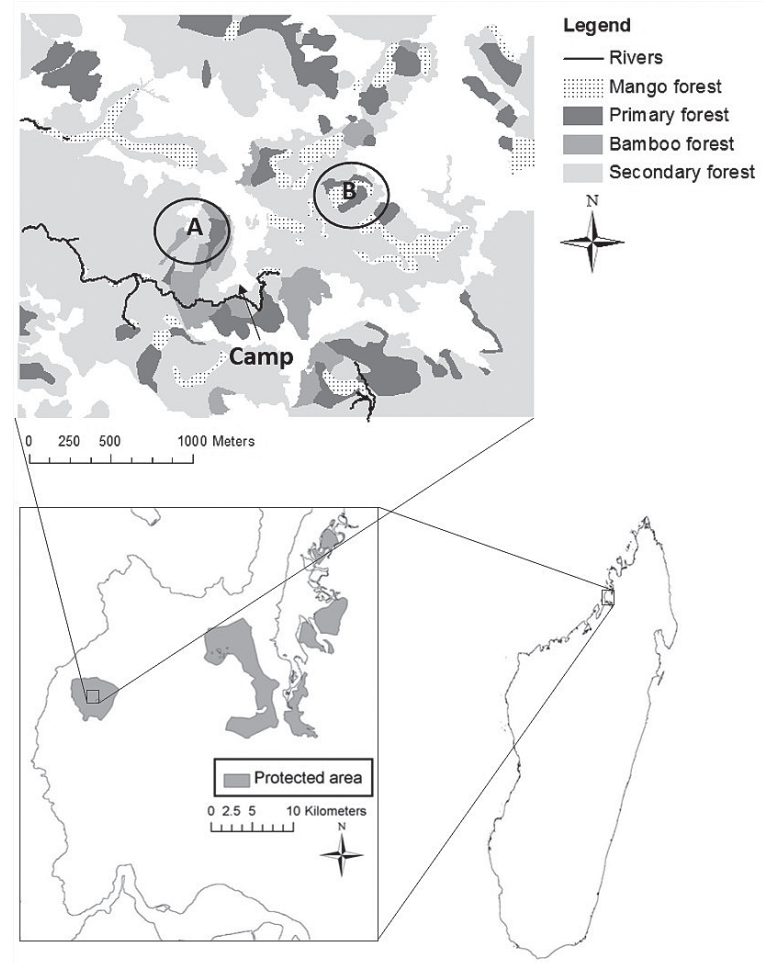

Fig. 1. Ankarafa Forest (top) showing Forests A and B and the location of the research camp. The research sites are located on the Sahamalaza Peninsula (bottom left) in north western Madagascar (bottom right). We retrieved the land cover map from the CEPF Madagascar Vegetation Mapping Project (Moat and Smith 2007); it was confirmed via ground-truthing by the Association Européenne pour 1'Etude et la Conservation des Lémuriens (AEECL). 
First, what are the height and position of nests of $M$. $z a z a$ ? Second, which nest site characteristics are selected by M. zaza? Finally, we aim to provide preliminary data on their social organisation by examining nest fidelity as well as the composition and stability of nest groups by using behavioural and genetic data. We test several hypotheses regarding the composition of mixed-sex groups (Radespiel et al., 2009): rearing groups: comprise females and their immature offspring; family groups: include both parents and their immature offspring; mating groups: comprise potential mates (unrelated males and females); social groups: include unrelated and/or related individuals, offering advantages of group living to members with respect to environmental challenges (low temperature, predation risk).

\section{Material and methods}

The study took place in the Ankarafa Forest, northwestern Madagascar, during the dry season for ten weeks from the beginning of May until mid-July 2010. Ankarafa Forest is situated on the Sahamalaza Peninsula (Sofia Region, Analalava District) within the boundaries of the UNESCO Biosphere Reserve and protected area Sahamalaza - Iles Radama (Fig. 1). The National Park extends between $13^{\circ} 52^{\prime}$ S and $14^{\circ} 27^{\prime} \mathrm{S}$, and $45^{\circ} 38^{\prime} \mathrm{E}$ and $47^{\circ} 46^{\prime} \mathrm{E}$ (Schwitzer et al., 2007). Sahamalaza is located in a transition zone between the Sambirano evergreen rainforest domain in the north and the western dry deciduous forest region in the south (Schwitzer and Lork, 2004; Schwitzer, 2005). The strict seasonal climate of this zone is represented by a dry and cool season from May to September and a rainy and hot season from October to April. Mean annual rainfall is $1600 \mathrm{~mm}$, mean annual temperature $28.0^{\circ} \mathrm{C}$ and monthly mean temperatures range from $20.6{ }^{\circ} \mathrm{C}$ in August to $32.0^{\circ} \mathrm{C}$ in November (Schwitzer et al., 2007). Due to traditional slash and burn agriculture and clearance for cattle herds, only fragments of primary and secondary forest interrupted by savannah remain (Fig. 1) (Schwitzer and Lork, 2004; Schwitzer et al., 2007).

We captured M. zaza using 30 live traps (Tomahawk Live Traps size 12). Following the advice of experienced local guides the traps were placed systematically in heights of $1.5 \mathrm{~m}$ above the ground in two forest fragments (separated by $250 \mathrm{~m}$ of savannah) hereafter called Forest A and B. We baited the traps with banana in the evening and checked them in the early morning (Kappeler et al., 2005). Towards the end of the study, we checked traps as early as $2100 \mathrm{~h}$ and again at $0000 \mathrm{~h}$, as we observed that animals entered the traps right after starting their activity. We captured five males and three females in May, all of which were recaptured in July. Four additional animals (two females and two males) were captured in July and added to our genetic analyses.

We anesthetized captured M. zaza with Ketamine (10 mg/kg body mass) (Lahann, 2008), took standard morphometric measurements and small ear biopsies (2 $\times 2 \mathrm{~mm}$ in the outer pinnae) with an ear punch (Kent Scientific Corporation, US). Adult animals were defined as weighing more than $250 \mathrm{~g}$ (Kappeler, 1997; Markolf, pers. comm.), sub-adult animals between 200 and $250 \mathrm{~g}$ and juveniles less than $200 \mathrm{~g}$. We regarded enlarged nipples as a sign of sexual maturity in females. Sub-adults and juveniles looked substantially smaller than adults, and could be clearly determined by sight. We fitted eight animals with TW3 rubbercoated cable tie radio-collars (Biotrack Ltd., UK, 3-4 $\mathrm{g}$ ), which we removed at the end of the study. We used a TR-4 receiver (Telonics Inc., USA; frequency range 150.545-150.969 MHz) and flexible Yagi antenna (Biotrack Ltd., UK) to locate the animals. Two teams carried out ad libitum observations twice daily, during emergence from the nest between $1700 \mathrm{~h}$ and $1800 \mathrm{~h}$ and return to the nest between $0400 \mathrm{~h}$ and $0600 \mathrm{~h}$. The group nests that we did not observe directly we confirmed via radio-tracking at $1700 \mathrm{~h}$ or $0600 \mathrm{~h}$, respectively. We later verified unknown nest sites by observing the animals emerge from or return to the nests. Nest characteristics were measured as nest height in tree, distance from top of tree, position in tree (trunk, branch or leaves), number of lianas or branches connected to the nest and number of routes such as specific branches or lianas regularly used by the animals to access the nest (Garcia and Braza, 1993). We only counted lianas if they were deemed strong enough to

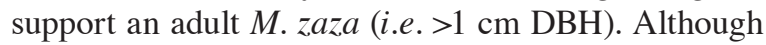
only one nest was fully visible, the location of the nests could be estimated to the nearest meter.

We collected data on all sleeping trees, trees used by the animals during the night when they were active, and on random trees. We identified used trees during focal instantaneous scan sampling with 15-minute intervals (Altmann, 1974). We determined random centre trees a priori by calculating fifty random coordinate pairs lying between the minimum and maximum of the group home range's easting and northing coordinates and choosing the nearest tree to this point. We omitted 
random points falling outside the home range or in inappropriate habitat (adjacent savannah). In order to collect microhabitat data we used these trees as centre trees and selected four further trees using the pointcentred quarter method (Ganzhorn, 2003). We recorded the variables tree species, tree height, diameter at breast height (DBH), crown diameter (horizontally at the broadest point), number of lianas and number of connected trees for all centre and microhabitat trees. Additionally, we measured the distance from microhabitat trees to the centre trees an indication of tree density. We measured distance between trees to the nearest $\mathrm{cm}$, while tree height and crown diameter were estimated to the nearest meter and averaged between the estimates of two observers. We only considered trees with stems larger than $10 \mathrm{~cm} \mathrm{DBH}$. Central tendencies are reported as medians due to skewed frequency distribution. Two guides determined the local vernacular names of trees, and staff of the Missouri Botanical Garden based in Antananarivo translated these into scientific names.

We monitored nest sites via radio-tracking once during the day and during emergence and return of the animals in the evening and morning via direct observation. We counted the number of animals sleeping in a nest and determined the sex and age composition via radio-tracking when animals were leaving or returning. A nest group was defined as all animals sleeping in one nest in the majority of observations. During direct observations we could observe the animals well and were thus confident that no additional, un-collared animal left or entered the nest. Return and emergence times from the nests and behaviour before entering and after emergence of the nest until the animals were out of sight were recorded for each animal ad libitum. Even though the exact location of one nest could only be estimated, animals could be seen emerging and returning. We determined the number of different sleep- ing sites per individual and return rate (number of returns to a nest divided by the total of possible returns, Radespiel et al., 1998). Furthermore, we calculated togetherness as the average number of sleeping sites used by a nest group, and the size of an average sleeping group aggregation during days when all animals of a nest group could be detected, both varying between 1 and $n$, where $n$ is the number of animals in one nest group. Neither the tree nor tree habitat variables were normally distributed (Kolmogorov-Smirnoff goodnessof-fit test: $\mathrm{p}<0.05)$. Accordingly we used KruskalWallis ANOVAs to compare tree variables of sleeping trees, used trees and random trees in two forest fragments A and B, followed by Mann-Whitney U tests (two-tailed) as post hoc tests for differences between variables of sleeping trees, used trees and random trees. The same was done for microhabitat variables. We applied a Bonferroni correction and set the significance level to 0.0125 (Cabin and Mitchell, 2000). We performed tests according to Dytham (2003) using SPSS 17.0.

We extracted DNA from the tissue samples using a standard phenol-chloroform protocol (Sambrook et al., 1989) at the University of Veterinary Medicine Hannover (TiHo). We determined microsatellite genotypes at the German Primate Centre, Germany, and we sequenced part of the Hypervariable region I (d-loop) at the TiHo Hannover. Microsatellite primers originally established via cross species amplification were taken from Markolf et al. (2008). For primer sequences and PCR conditions we refer to the original publications: Mm42 (Hapke et al., 2003a); Mm58, 110 (Hapke et al., 2003b); C1P3, Mm08 (Radespiel et al., 2001). In a $30 \mu 1 \mathrm{PCR}$ reaction, $19.34 \mu 1 \mathrm{H}_{2} \mathrm{O}, 3 \mu 1$ 10x buffer (contains $15 \mathrm{mM} \mathrm{MgCl}_{2}$, Biotherm), $4 \mu \mathrm{l} \mathrm{BT} \mathrm{(50} \mathrm{ml} \mathrm{contain}$ $5 \mathrm{ml}$ BSA $100 \mathrm{mg} / \mathrm{ml}, 250 \mathrm{~g}$ Triton X100 and $\mathrm{H}_{2} \mathrm{O}$ ), 0.1 $\mu 1$ of each primer $(100 \mathrm{pmol} / \mu \mathrm{l}), 0.2 \mu \mathrm{l}$ dNTPs $(25$ $\mathrm{mM}$ ), $0.2 \mu \mathrm{l}$ DNA polymerase (Biotherm, $5 \mathrm{u} / \mu \mathrm{l}$ ) and 3

Table 1. Characteristics of five microsatellite loci in the study population (12 individuals). $\mathrm{N}=$ sample size, Min = minimum allele size (length in bp), Max = maximum allele size (length in bp), $\mathrm{H}_{0}=$ observed heterozygosity, $\mathrm{H}_{\mathrm{e}}=$ expected heterozygosity, $\mathrm{HWE}=\mathrm{Hardy}$ Weinberg Equilibrium. *Indicates significant deviation from HWE $(\mathrm{p}<0.05)$.

\begin{tabular}{|c|c|c|c|c|c|c|c|c|}
\hline Locus & $\begin{array}{l}\text { Number of } \\
\text { gene copies }\end{array}$ & $\mathrm{N}$ & Alleles & Min & $\operatorname{Max}$ & $\mathrm{H}_{0}$ & $\mathrm{H}_{\mathrm{e}}$ & HWE \\
\hline Mm42 & 24 & 12 & 5 & 157 & 179 & 0.75 & 0.80 & - \\
\hline Mm58 & 24 & 12 & 5 & 94 & 108 & 0.67 & 0.70 & - \\
\hline 110 & 22 & 11 & 4 & 154 & 164 & 0.57 & 0.65 & - \\
\hline C1P3 & 24 & 12 & 3 & 175 & 181 & 0.08 & 0.47 & $*$ \\
\hline Mm08 & 24 & 12 & 4 & 188 & 196 & 0.67 & 0.71 & - \\
\hline
\end{tabular}


$\mu \mathrm{l}$ (25-75 ng) DNA were used. We diluted PCR reactions at 1:100 - 1:2000 and analysed on an automated capillary sequencer (ABI3100, Applied Biosystems). We scored alleles using Genemapper version 4.0 (Applied Biosystems). Table 1 shows characteristics of microsatellite loci.

We amplified the d-loop with the primers L15997 and H16498 (Guschanski et al., 2007) in a total volume of $25 \mu \mathrm{l}$ containing $0.8 \mu \mathrm{M}$ of each primer, $3 \mathrm{mM}$ $\mathrm{MgCl}_{2} 0.04 \mathrm{mM}$ of each dNTP, $1 \times$ buffer (NH4-reaction buffer (50 mM Tris- $\mathrm{HCl} \mathrm{pH} 8.8,16 \mathrm{mM}\left(\mathrm{NH}_{4}\right)_{2} \mathrm{SO}_{4}$, $0.1 \%$ Tween $\left.{ }^{\circledR} 20\right)$ ) and 1.25 U Taq DNA Polymerase and $2 \mu \mathrm{l}$ DNA with the amplification conditions described in Guschanski et al. (2007). We checked amplified products on a $1.5 \%$ agarose gel and cleaned PCR products with the Invisorb ${ }^{\circledR}$ Spin PCRapid kit (Invitek). We sent purified products to the company Macrogen (Seoul, South Korea, www.macrogen.org) for sequencing in both directions on an ABI capillary sequencing platform, and we analysed, edited aligned and compared sequences using Sequencher ${ }^{\mathrm{TM}} 5.0$ (Gene Codes). All unique haplotypes are available from GenBank under the accession numbers JX105436 - JX105438.

We used the relatedness estimator (r) to investigate relatedness between sleeping group members (Queller and Goodnight, 1989). We estimated pairwise relatedness for all possible dyads of all twelve captured individuals with the software Kingroup 2.10.12.02 (Konovalov et al., 2004) and compared r-values of co-sleepers $(n=14)$ with those of dyads consisting of individuals sleeping in different groups (non-co-sleepers, $\mathrm{n}=$ 77), using an unpaired Mann-Whitney-U test computed in the software $\mathrm{R}$ (version 2.12.2).

Concerning the reconstruction of kinship relationships, no conclusions could be made from a pairwise comparison of relatedness, since for our small sample any estimator of relatedness should be highly affected by stochastic differences in IBD (Identity By Descent) among loci and by the chance of sharing the same alleles (Blouin, 2003). Additionally, it remains unclear whether we sampled a (small) representative crosssection of the population within each forest fragment or only individuals from one lineage. Therefore, we only inferred which dyads reach a level of relatedness compatible to first degree relatives (parent-offspring and full-sib dyads) by comparing individual genotypes, r-values, corresponding p-values calculated by Kingroup based on the method of Guo and Thompson (1992), and mitochondrial haplotypes, but these analyses have to be regarded as a preliminary attempt to infer kinship relations. We focused on first-degree relatives, because for them it should be easier to differentiate IDB from chance sharing of alleles.

\section{Results}

\section{Nests and nest sites}

We found seven sleeping trees by following the eight animals we captured and radio-collared in May. Four nests were located in Forest A, and three in Forest B (Fig. 2). The attributes of six nests are described in Table 2. Median distance from the top of the tree was $1.5 \mathrm{~m}(\mathrm{n}=6)$. Five of the nests were located either on or maximally $1 \mathrm{~m}$ away from the trunk, while one was located on a branch of $1 \mathrm{~m}$ diameter, approximately 3 $\mathrm{m}$ away from the main trunk. All locations were well covered by canopy. The animals used one to three different routes to leave or return to their nests.

Sleeping trees were significantly higher and had more lianas than the average of all used trees in both forests (Table 3). Differences between sleeping trees and random trees were only found in Forest B: sleeping trees were characterised by significantly more lianas.

We found no differences between the nest microhabitat and used and random microhabitats, respectively (Table 4). Sleeping tree species were Macarisia lanceolata, family Rhizophoraceae $(3 \times)$, Garcinia pauciflora, family Clusiaceae $(2 \times)$, Sorindeia madagascariensis, family Anacardiaceae $(1 \times)$ and Canarium madagascariense, family Burseraceae $(1 \times)$.

\section{Nest utilisation}

Focal animals belonged to three different nest groups that were located in their nests on 24, 16 and 31 days per group, respectively. We were able to observe animals during emergence and return on 26 evenings and 24 mornings. The total time of ad libitum nest behaviour observations before returning and after emergence comprised 41.5 hours.

Group size of the three nest groups was two to four individuals (Fig. 3). Nest Groups 1 and 3 contained only one (sub-adult) female but several mature males. Maturity was assumed as these males had fully developed testes. Nest Group 2 usually consisted of an adult female and her young. Nests were exclusively used by one group only. Only once did we observe another individual entering a nest (see below). A fourth group is shown in Fig. 3, but although animals were captured at 

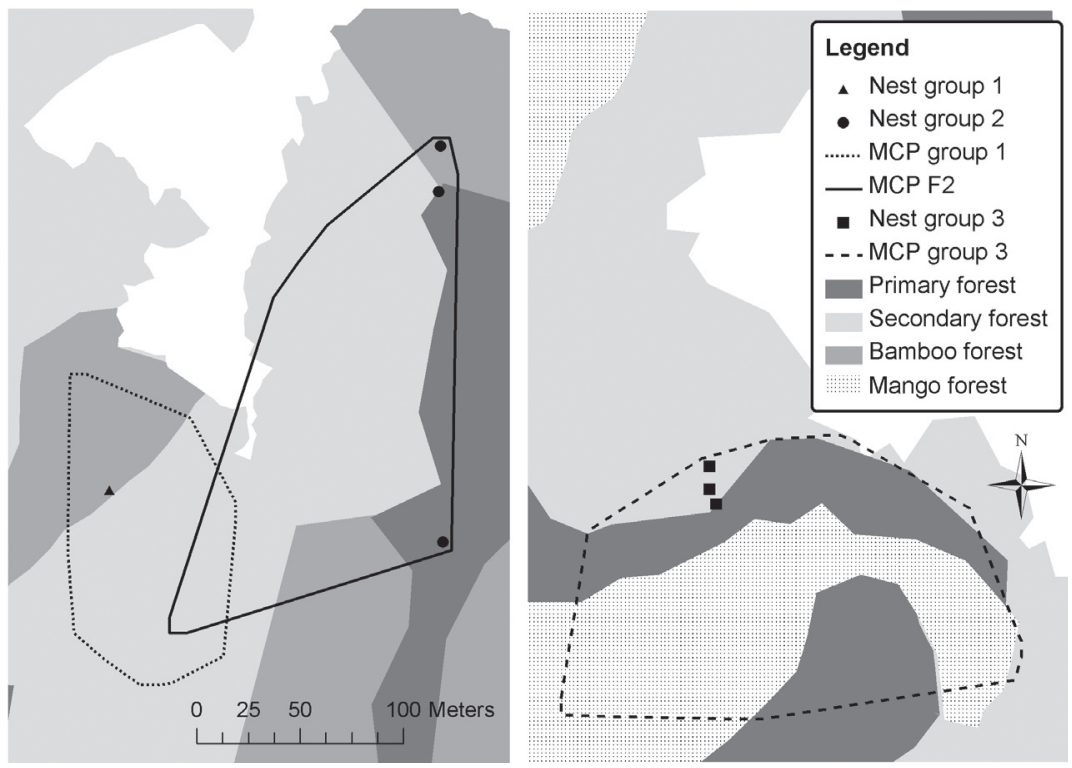

Fig. 2. Locations of seven sleeping trees within the observed home ranges of Nest Groups 1,2 and 3 in two different forests (A and B). As only one animal was radiocollared in group 2, the home range is only shown for one animal (F2). We defined mango forest as containing more than $10 \%$ mango trees. White areas depict non-forest matrix. Animals used all forest types. We show home ranges as $100 \%$ Minimum Convex Polygon (Kenward, 2001) during follows with 15-minute sampling intervals (Rode, 2010).

the same site it is unclear if they represented a nest group.

The three groups used one, three and three different sleeping trees, respectively. On all days of direct observation the nest group compositions were stable, that is, all group members but no additional animals slept in the nest. Only on three days we observed an unidentified animal sleeping in the nest of Group 2, consisting of a female and her young.

Return time in the morning was between $412 \mathrm{~h}$ and 547h (mean 528h, SD 17:14 min, $\mathrm{n}=42$ ). In the evening the animals emerged from the nests between $1722 \mathrm{~h}$ and 1749h (mean 1736h, SD 5:52 min, $\mathrm{n}=63$ ). When emerging from nests the individuals left the nest site immediately. At their return they often entered the area before sunrise and engaged in grooming and social behaviour such as playing. The latter was only observed between mixed-sex pairs. Allogrooming was observed once between two males.

Group 1 stayed in the same nest during all 24 sampling days over a 44-day period. Group 2 was located in three nests during all 16 sampling days in a 35-day period. This group swapped between two close sleeping trees during a 19-day period (9 sampling days), but after a storm lasting eight days they changed their nest to a new area. We detected Group 3 on 31 sampling days during a 50-day period; they used three close nests during this time. A swap between two of these nests took one week, during which one or two individuals alternately slept in the new nest on different nights until the whole group settled there. The old nest disintegrated quickly during a storm. General return rate (actual individual returns divided by possible individual returns) of all M. zaza was high, with an average of $91.9 \%$ (SD $11.3 \%, \mathrm{n}=8$ ). Togetherness in Group 1 was 1 and average sleeping group aggregation size was 4 ( $\mathrm{n}=13,4$ animals). In Group 2 togetherness was 1.3 $(\mathrm{n}=20,3$ animals) and average sleeping group aggregation size 2.31 ( $\mathrm{n}=26,3$ animals).

Allelic diversity of microsatellites was comparably low (Markolf et al., 2008). A summary of the characteristics of the five microsatellite loci is given in Table 1. Maximum number of detected alleles was five, though length differences of detected alleles ranged up to 22bp. Mean relatedness within sleeping groups ranged between -0.11 and 0.35 (Fig. 3). The microsatellite data showed a relatively low genetic diversity with few alleles and low levels of heterozygosity (Table 1). Genetic diversity was also very low in the mitochondrial sequences, as a total of three haplotypes were found that differed from each other in only 1-3 bp. In one sleeping group (Group 3) mean relatedness was slightly lower than the mean relatedness estimate of all twelve individuals $\left(\mathrm{r}_{\text {mean }}=-0.08\right)$. The composition of sleeping groups appeared to vary in respect to the presence of related individuals. Nevertheless, relatedness of co-sleeping dyads $(n=14$, mean $r=0.06)$ was higher than relatedness within non-co-sleeping dyads $(\mathrm{n}=77$, mean $\mathrm{r}=-0.12$, unpaired Wilcoxon rank sum test: $\mathrm{W}=471$, $\mathrm{p}$-value $=0.04$ ). 
Table 2. Height, distance from top of the tree, and number of liana substrates of six nests of Mirza zaza.

\begin{tabular}{|c|c|c|c|c|c|}
\hline Nest & Group & Forest & Height of nest (m) & Distance from top (m) & Lianas (no.) \\
\hline 1 & 1 & A & 14 & 2 & 5 \\
\hline 2 & 2 & A & 12 & 3 & 20 \\
\hline 3 & 2 & A & 18 & 1 & 10 \\
\hline 4 & 2 & $\mathrm{~A}$ & 22 & 11 & 50 \\
\hline 5 & 3 & $\mathrm{~B}$ & 12 & 1 & 13 \\
\hline 6 & 3 & $\mathrm{~B}$ & 11 & 1 & 5 \\
\hline Median & & & 13 & 1.5 & 11.5 \\
\hline
\end{tabular}

Table 3. Medians of five sleeping tree variables and comparison to used and random trees in Forests A and B. Height and crown diameter were estimated to the nearest meter. Asterisks indicate significant differences between the respective column and the sleeping trees (Mann-Whitney-U tests with Holm's sequential Bonferroni correction after Kruskal-Wallis-ANOVA). Empty cells indicate where no data were available. Significance level of post hoc Mann-Whitney-U tests was set to $\mathrm{p}<0.0125$ and indicated by $\mathrm{p}<0.05 *$, p $<0.01 * *$, $\mathrm{p}$ $<0.001 * * *$. Sample size for used trees forest B: DBH: $\mathrm{n}=164$. Height and crown diameter: $\mathrm{n}=65$.

\begin{tabular}{|c|c|c|c|c|c|c|c|}
\hline & & \multicolumn{6}{|l|}{ Median } \\
\hline & & $\begin{array}{l}\text { Sleeping } \\
\text { tree }\end{array}$ & $\begin{array}{l}\text { Used trees } \\
\text { Forest A }\end{array}$ & $\begin{array}{l}\text { Used trees } \\
\text { Forest B }\end{array}$ & $\begin{array}{l}\text { Random trees } \\
\text { forest A }\end{array}$ & $\begin{array}{l}\text { Random trees } \\
\text { forest B }\end{array}$ & $\begin{array}{l}\text { Kruskal Wallis } \\
\text { ANOVA }\end{array}$ \\
\hline \multirow[t]{5}{*}{ Height (m) } & median & 16.50 & $11.50 * *$ & $12.00 * *$ & $12.00 *$ & $12.50 *$ & $\mathrm{p}=0.018$ \\
\hline & percentile 25 & 12.47 & 8.00 & 11.00 & 10.88 & 10.00 & \\
\hline & percentile 75 & 18.97 & 13.00 & 15.00 & 14.57 & 14.50 & \\
\hline & $\min$ & 11.71 & 5.50 & 8.00 & 6.38 & 3.00 & \\
\hline & $\max$ & 33.26 & 19.00 & 19.00 & 20.25 & 24.50 & \\
\hline \multirow[t]{5}{*}{$\mathrm{DBH}(\mathrm{cm})$} & median & 29.9 & 17.6 & 18.8 & 16.6 & 15.2 & $\mathrm{p}=0.140$ \\
\hline & percentile 25 & 16.0 & 12.4 & 14.0 & 12.7 & 12.1 & \\
\hline & percentile 75 & 38.2 & 21.7 & 23.2 & 23.1 & 20.5 & \\
\hline & $\min$ & 13.69 & 10.19 & 10.19 & 10.00 & 10.00 & \\
\hline & $\max$ & 197.35 & 70.03 & 49.02 & 69.07 & 63.66 & \\
\hline \multirow[t]{5}{*}{ Crown diameter $(\mathrm{m})$} & median & 8.50 & 6.00 & 6.00 & 6.00 & $5.00 *$ & $\mathrm{p}<0.001$ \\
\hline & percentile 25 & 5.00 & 4.00 & 4.00 & 5.00 & 3.00 & \\
\hline & percentile 75 & 11.00 & 7.50 & 7.50 & 7.00 & 6.50 & \\
\hline & $\min$ & 4.50 & 0.00 & 1.50 & 3.00 & 0.00 & \\
\hline & $\max$ & 16.00 & 14.00 & 12.50 & 13.13 & 12.50 & \\
\hline \multirow[t]{5}{*}{ Lianas (no.) } & median & 15 & $2 * * *$ & $2 * * *$ & & $2 * * *$ & $\mathrm{p}=0.001$ \\
\hline & percentile 25 & 10 & 0 & 1 & & 1 & \\
\hline & percentile 75 & 30 & 4 & 6 & & 5 & \\
\hline & $\min$ & 5 & 0 & 0 & & 0 & \\
\hline & $\max$ & 65 & 11 & 13 & & 30 & \\
\hline \multirow[t]{5}{*}{ Connectivity (no.) } & median & 3 & 3 & 4 & & 2 & $\mathrm{p}<0.001$ \\
\hline & percentile 25 & 1 & 2 & 3 & & 1 & \\
\hline & percentile 75 & 5 & 3 & 5 & & 3 & \\
\hline & $\min$ & 0 & 0 & 1 & & 0 & \\
\hline & $\max$ & 6 & 6 & 8 & & 8 & \\
\hline $\mathrm{n}$ & & 7 & 45 & 55 & see caption & 228 & \\
\hline
\end{tabular}

According to the comparison of individual genotypes, r-values and mitochondrial haplotypes, we found eight dyads that reached a level of relatedness compatible with first degree relatives, one male-male dyad, five male-female and two female-female dyads
(Table 5, Fig. 3). If these relationships could be corroborated through further data, this would mean that for Mirza zaza, first-degree relatives could be found within and between sleeping groups. Not all closely-related animals, however, shared the same mitochondrial 
Table 4. Medians for seven variables of microhabitat and comparison to used microhabitat and random microhabitat in Forests A and B. Asterisks indicate significant differences between the respective column and the nest habitat (Mann-Whitney-U tests with Holm's sequential Bonferroni correction after Kruskal-Wallis-ANOVA). Values for random habitat can be found in Table 3. Empty cells indicate where no data were available. Significance level of post hoc Mann-Whitney-U tests was set to $\mathrm{p}<0.0125$ and indicated by $\mathrm{p}<0.05 *$, $\mathrm{p}<0.01 * *, \mathrm{p}<0.001 * * *$.

\begin{tabular}{|c|c|c|c|c|c|}
\hline & & \multicolumn{4}{|l|}{ Median } \\
\hline & & Nest habitat & $\begin{array}{l}\text { Used habitat } \\
\text { Forest A }\end{array}$ & $\begin{array}{l}\text { Used habitat } \\
\text { Forest B }\end{array}$ & $\begin{array}{l}\text { Kruskal Wallis } \\
\text { ANOVA }\end{array}$ \\
\hline \multirow[t]{5}{*}{ Height (m) } & median & 12 & & 12 & $\mathrm{p}=0.273$ \\
\hline & percentile 25 & 10.25 & & 10 & \\
\hline & percentile 75 & 14 & & 14 & \\
\hline & $\min$ & 3.5 & & 3.5 & \\
\hline & $\max$ & 24 & & 24.5 & \\
\hline \multirow[t]{5}{*}{ DBH (cm) } & median & 16.6 & $14.0 *$ & 14 & $\mathrm{p}=0.007$ \\
\hline & percentile 25 & 13.7 & 11.8 & 11.8 & \\
\hline & percentile 75 & 22.6 & 17.8 & 19.7 & \\
\hline & $\min$ & 10.2 & 10 & 10 & \\
\hline & $\max$ & 66.9 & 63.7 & 63.7 & \\
\hline \multirow[t]{5}{*}{ Crown diameter $(\mathrm{m})$} & median & 4.5 & & 4.5 & $\mathrm{p}<0.001$ \\
\hline & percentile 25 & 3.5 & & 3 & \\
\hline & percentile 75 & 6.5 & & 6 & \\
\hline & $\min$ & 0 & & 0 & \\
\hline & $\max$ & 13.5 & & 18 & \\
\hline \multirow{5}{*}{ Lianas (no.) } & median & 1 & & 2 & $\mathrm{p}=0.406$ \\
\hline & percentile 25 & 0 & & 0 & \\
\hline & percentile 75 & 6 & & 4 & \\
\hline & $\min$ & 0 & & 0 & \\
\hline & $\max$ & 22 & & 25 & \\
\hline \multirow[t]{5}{*}{ Connectivity (no.) } & median & 2 & & 3 & $\mathrm{p}=0.012$ \\
\hline & percentile 25 & 1 & & 2 & \\
\hline & percentile 75 & 3 & & 4 & \\
\hline & $\min$ & 0 & & 0 & \\
\hline & $\max$ & 4 & & 9 & \\
\hline \multirow{5}{*}{ Distance (m) } & median & 4.45 & 3.98 & 3.9 & $\mathrm{p}<0.001$ \\
\hline & percentile 25 & 2.78 & 2.68 & 2.39 & \\
\hline & percentile 75 & 6.44 & 6.2 & 5.36 & \\
\hline & $\min$ & 0.33 & 0.43 & 0.32 & \\
\hline & $\max$ & 11.8 & 16.26 & 15.4 & \\
\hline $\mathrm{n}$ & & 28 & 204 & 212 & \\
\hline
\end{tabular}

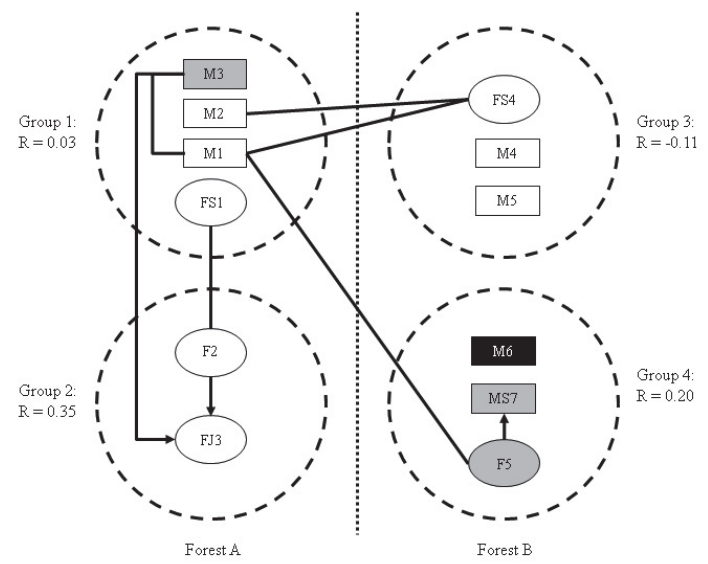

Fig. 3. Genetic relatedness and composition of sleeping groups of Mirza zaza in forests A and B. Circles: females; boxes: males. $\mathrm{M}=$ male, $\mathrm{F}=$ female, $\mathrm{S}=$ sub-adult, $\mathrm{J}=$ juvenile. All individuals are adults unless specifically stated. Arrows pointing from parents towards their potential offspring: thick lines indicate firstdegree relatives. Mean relatedness for group is provided. Different shadings (white, grey, black) represent three different haplotypes that differ in 1,2 and 3 base pairs. 
haplotype, i.e., belonged to the same matriline. Relatedness may therefore partly have paternal origins (e.g. dyad M1/M3). It can be assumed that F2 was the mother of FJ3 (141 g) as they were sleeping in one nest, belonged to the same mt haplotype, had matching genotypes for all five microsatellite loci, were often seen together during nocturnal activities, and F2 had enlarged nipples. Co-sleeping adult males were unrelated except for one dyad (M1/M3) with an r-value of 0.72 , which had no mismatches for the microsatellites but mismatching mitochondrial haplotypes.

\section{Discussion}

\section{Nests and nest sites}

Often predation is suggested to be of high importance in the selection of sleeping sites (Hamilton, 1982; Fan and Jiang, 2008). Goodman et al. (1993) reported an individual of $M$. coquereli caught by a Madagascar buzzard (Buteo brachypterus Hartlaub, 1860) and several individuals found with scars, indicating an attack by the raptor. Since Buteo, as well as other raptors like the Madagascar harrier hawk (Polyboroides radiatus (Scopoli, 1786)), is diurnal, Goodman and colleagues suggested that the lemurs were caught from their nests. Furthermore, remains of Mirza have been found in scats of Cryptoprocta ferox Bennett, 1833 (Rasoloarison et al., 1995), which hunts during day and night (Karpanty and Wright, 2007). In the sub-humid forests of Sahamalaza National Park most of the trees keep their foliage even during the six-month dry season
(Schwitzer, 2005), which provides basic cover from a predator's view. Additionally, selecting nest sites in dense vegetation provides good camouflage and improves concealment (Bearder et al., 2003). Accordingly, due to dense foliage, only one nest of M. zaza could be seen directly in our study. Mirza zaza preferred tall and large sleeping trees with many lianas. Pages (1980) reported that sleeping trees of M. coquereli were usually covered in lianas. The high number of lianas covering the sleeping trees might decrease the risk of being detected by predators (Garcia and Braza, 1993; Rendigs et al., 2003). The nests were located a few meters below the top of sleeping trees, which was also reported for M. coquereli (Sarikaya and Kappeler, 1997). The hidden and high position suggests good protection against both aerial and ground predators (Rasoloarison et al., 1995). Mirza zaza used one to three different routes to leave or access the nests. Reuse of such routes was especially evident for the single used tree of Group 1 where three of four animals always used exactly the same branches of the nest and neighbouring tree to leave the site. Similar behaviour was observed for owl monkeys (Garcia and Braza, 1993) and slender lorises (Nekaris, 2006). Knowing escape routes in case of a predator attack should be advantageous (Aquino and Encarnación, 1986; Wells et al., 2006).

Environmental factors may also influence sleeping site choice (Aquino and Encarnación, 1986), which has been suspected for orang-utans (Ancrenaz et al., 2004). Strong winds such as the Varatraza or the Talio can occur in the region during the dry period (Schwitzer et al., 2007), and severe tree fall was common during

Table 5. R-values (above diagonal) and respective P-values (below diagonal) for all possible dyads of 12 Mirza zaza. Grey shadings indicate sleeping group dyads. $\mathrm{F}=$ adult female, $\mathrm{FS}=$ sub-adult female, $\mathrm{FJ}=$ juvenile female, $\mathrm{M}=$ adult male, $\mathrm{MS}=$ sub-adult male.

\begin{tabular}{llllllllllllllrr}
\hline ID & $\begin{array}{l}\text { Sleeping } \\
\text { group }\end{array}$ & $\begin{array}{l}\text { Mitoch. } \\
\text { haplotype }\end{array}$ & M1 & M2 & FS1 & M3 & FJ3 & F2 & M4 & M5 & FS4 & M6 & F5 & MS7 \\
\hline M1 & 1 & H3 & & -0.11 & -0.10 & 0.72 & 0.18 & -0.17 & -0.16 & -0.45 & 0.48 & -0.37 & -0.39 & 0.30 \\
M2 & 1 & H3 & 0.50 & & 0.11 & -0.21 & 0.07 & 0.05 & -0.11 & 0.16 & 0.35 & -0.32 & -0.66 & -0.15 \\
FS1 & 1 & H3 & 0.49 & 0.25 & & -0.21 & -0.08 & 0.69 & -0.47 & 0.03 & -0.29 & -0.31 & -0.10 & 0.02 \\
M3 & 1 & H2 & 0.00 & 0.63 & 0.62 & & 0.45 & -0.27 & -0.24 & -0.64 & 0.42 & -0.32 & -0.30 & 0.12 \\
F2 & 2 & H3 & 0.58 & 0.29 & 0.00 & 0.69 & 0.07 & & -0.41 & -0.14 & -0.37 & -0.15 & 0.02 & 0.31 \\
FJ3 & 2 & H3 & 0.18 & 0.28 & 0.45 & 0.03 & & 0.35 & -0.39 & -0.50 & 0.00 & -0.35 & -0.15 & 0.15 \\
M4 & 3 & H3 & 0.57 & 0.50 & 0.90 & 0.67 & 0.83 & 0.85 & & -0.12 & -0.05 & -0.15 & -0.61 & -0.60 \\
M5 & 3 & H3 & 0.88 & 0.19 & 0.32 & 0.98 & 0.92 & 0.53 & 0.50 & & -0.15 & 0.48 & -0.18 & -0.29 \\
FS4 & 3 & H3 & 0.03 & 0.07 & 0.72 & 0.04 & 0.36 & 0.81 & 0.42 & 0.55 & & -0.18 & -0.42 & 0.29 \\
M6 & 4 & H1 & 0.81 & 0.76 & 0.75 & 0.76 & 0.79 & 0.55 & 0.55 & 0.03 & 0.58 & & 0.19 & 0.03 \\
F5 & 4 & H2 & 0.82 & 0.99 & 0.48 & 0.73 & 0.55 & 0.34 & 0.97 & 0.59 & 0.86 & 0.17 & \\
MS7 & 4 & H2 & 0.09 & 0.55 & 0.33 & 0.23 & 0.20 & 0.09 & 0.96 & 0.73 & 0.10 & 0.32 & 0.06 & 0.38 \\
\hline
\end{tabular}


several weeks of the study period. Selecting robust trees and a nest site near the tree trunk may be related to the importance of solid support.

\section{Nest utilisation}

Nest groups of $M$. zaza were stable in composition, with one exception where the inclusivity of one male was unclear, and did not change during the study period. A third adult individual of Group 2 was occasionally observed but may have joined the group for only a few days. In other species sleeping groups were not only stable in dispersed pairs or families (Lepilemur edwardsi (Forbes, 1894) - Rasoloharijaona et al., 2003; Microcebus murinus - Radespiel et al., 1998; Cheirogaleus medius É. Geoffroy, 1812 - Müller, 1999), but also in mixed-sex groups of Microcebus ravelobensis (Weidt et al., 2004).

Nests were group-exclusive and groups stayed in the same nest during long time periods of up to at least 44 days (Group 1). Only up to three nests were used by each group, resulting in high return rates. In contrast, Kappeler et al. (2005) found individuals of M. zaza using two to five different nests on the three to seven days they could be located. Kappeler et al. (2005) conducted their study in March, April and October, and nest use might change seasonally. Only in Group 3 animals sometimes slept in different nests. Lepilemur edwardsi showed similarly high nest site fidelity as M. zaza, with two to three close nest sites (Rasoloharijaona et al., 2003), while for instance female Microcebus murinus used three to seven sites (Radespiel et al., 1998). Weidt et al. (2004) reported M. ravelobensis staying in one nest for a maximum of 16 successive days. There may be two non-exclusive explanations for a small number of unique nest sites. The continuous use and reuse of certain trees may increase due to the loss of suitable trees in degraded or logged forests (Ancrenaz et al., 2004). Less frequent change of nest sites may therefore be a function of low habitat quality. Alternatively, observed nest sites of Mirza zaza may be very high in quality, which would decrease the necessity for changing the site. For example, males of Microcebus murinus change their low-quality sleeping sites frequently, probably in order to decrease predation risk (Radespiel et al., 1998). Both explanations would normally lead to intensive intraspecific competition between groups for this resource and animals trying to monopolize high quality nest sites, as suggested for Lepilemur edwardsi (Rasoloharijaona et al., 2003), M. ravelobensis (Braune et al., 2005) or M. murinus (Radespiel et al., 1998).
Groups returned to the nest with an observed maximum time lag of 26 minutes between the first and the last individual. Individuals engaged in grooming, playing and other activities in the sleeping tree before permanently occupying the nest. They were often seen on the sleeping tree or neighbouring trees, grooming or engaging in social activities, as observed for L. l. lydekkerianus (Nekaris, 2003, 2006). Pages (1978) found that Mirza coquereli showed more social activities during the second half of the night compared to the first half where behaviour focused more on feeding.

Group 3 changed their nest gradually, with a single group member sleeping in the new tree at first, as also observed for L. l. lydekkerianus (Nekaris, 2003). In M. $z a z a$ every individual had slept in the new tree at least once before the entire group finally moved over as a unit. Similar patterns of nest changes were observed in Microcebus ravelobensis (Weidt et al., 2004) and Aotus (Aquino and Encarnación, 1986).

Mirza zaza differs from its sister species $M$. coquereli in its diurnal gregarious nesting behaviour. While $M$. coquereli mostly sleeps in nests alone, M. zaza was found to share nests between two to eight individuals (Kappeler et al., 2005). We observed nest groups of two to four individuals. During the dry season Microcebus murinus can gather in sleeping groups of up to 15 animals but average sleeping group size is usually much smaller for Malagasy nocturnal primates (Eberle and Kappeler, 2006). Bearder et al. (2003) report that galagines may sleep in groups of up to ten individuals, whereas the Mysore slender loris (L.l. lydekkerianus) sleeps in groups of up to seven (Nekaris, 2003). Interestingly, two groups we observed contained one subadult female and multiple adult males with fully developed testes. Kappeler et al. (2005) found on average 0.77 adult females and 1.06 adult males with fully developed testes in a nest. High numbers of adult males were only reported for a few other species. In L. l. lydekkerianus, several adult males were observed to sleep in a group with females and young, perhaps as a strategy to rear twin offspring (Nekaris, 2003).

Social organisation of nest groups can be inferred using a combination of genetic and behavioural results. At least two of the four sleeping groups were not "rearing" or "family groups", as several adult males were sharing the nest (Groups 1 and 3). Even though the results of the kinship analysis have to be treated with caution due to the low sample size, we are confident that two closely related males were sharing the nest in sleeping Group 1. This provides some support for the social groups hypothesis. The formation of so- 
cial groups may be explained by environmental challenges (Radespiel et al., 2001). Sahamalaza has a pronounced seasonal climate. The study was conducted in the dry season. Minimum nightly temperatures dropped to $10{ }^{\circ} \mathrm{C}$ in July and behavioural thermoregulation may be necessary. Predation risk may be another reason for social nest groups as detectability of predators increases with number of animals being alert (Elgar, 1989). Weidt et al. (2004) reported that some sleeping associations of Microcebus ravelobensis contained several adult males. This behaviour was suggested to represent a (temporary) mate guarding strategy where males have direct control and access to the females in their group instead of having to search for them (Weidt et al., 2004; Radespiel et al., 2009). Finally, the high rates of forest fragmentation and deforestation in the study area may affect the social organisation, as resources like nests or also mates may be limited. One indication for this might be the low genetic diversity of microsatellite loci and in the sequence data in comparison to Mirza coquereli (Markolf et al., 2008). Although gregarious nest behaviour by M. zaza was also observed in Ambato (Kappeler et al., 2005), we cannot be sure if this reflects their natural behaviour pattern. This should be further examined by comparing groups in intact, large forests to fragmented forests. If fragmentation and limitation of crucial resources has an impact on the social organisation, this might have negative consequences such as increased inbreeding.

\section{Conclusions and recommendations}

Two to four M. zaza, including multiple mature males, shared group-exclusive nests. Since nest-sharing male dyads consisted of either related or unrelated individuals, nest groups can be regarded as social groups, suggesting $M$. zaza lives in dispersed cohesive multimale/multi-female groups. We show a preference of M. zaza for large and tall sleeping trees with a high number of lianas. The animals used few sleeping trees, which may indicate scarcity of suitable trees within the respective home ranges. We recommend the protection of forest fragments with large and tall trees and discourage selective logging. We particularly recommend that trees suitable for use as sleeping sites by species such as $M$. zaza, such as those with a minimum DBH of $30 \mathrm{~cm}$ and a minimum height of approximately $16 \mathrm{~m}$, be considered in any habitat suitability assessment.

\section{Acknowledgements}

Many thanks to the Association Européenne pour l'Etude et la Conservation des Lémuriens (AEECL), Bristol Conservation and Science Foundation and the staff of the Madagascar Institute for the Conservation of Tropical Environments for their support. Thanks also to the MSc Primate Conservation staff and other anonymous reviewers that helped throughout the project and the preparation of this paper. Special thanks go to Rode's Malagasy research counterpart and the local guides at the Ankarafa Research Station, the staff of the Duke Lemur Center for providing life history data of Mirza zaza and Chris Birkinshaw (Missouri Botanical Garden, Antananarivo) for helping to translate Malagasy names of tree species. This study was supported by the MSc Primate Conservation at Oxford Brookes University, Conservation International's Primate Action Fund and Primate Conservation, Inc.

\section{References}

Altmann J. 1974. Observational study of behavior: sampling methods. Behaviour 49: 227-267.

Ancrenaz M, Lackman-Ancrenaz I, Mundy N. 1994. Field observations of aye-ayes (Daubentonia madagascariensis) in Madagascar. Folia Primatologica 62: 22-36.

Ancrenaz M, Calaque R, Lackman-Ancrenaz I. 2004. Orangutan nesting behavior in disturbed forest of Sabah, Malaysia: implications for nest census. International Journal of Primatology 25: 983-1000.

Anderson JR. 1998. Sleep, sleeping sites, and sleep-related activities: awakening to their significance. American Journal of Primatology 46: 63-75.

Aquino R, Encarnación F. 1986. Characteristics and use of sleeping sites in Aotus (Cebidae: Primates) in the Amazon lowlands of Peru. American Journal of Primatology 11: 319-331.

Bearder SK, Doyle GA. 1974. Field and laboratory studies of social organization in bushbabies (Galago senegalensis). Journal of Human Evolution 3: 37-50.

Bearder SK, Ambrose L, Harcourt C, Honess P, Perkin A, Pimley E, Pullen S, Svoboda N. 2003. Species-typical patterns of infant contact, sleeping site use and social cohesion among nocturnal primates in Africa. Folia Primatologica 74: 337-354.

Biebouw K, Bearder S, Nekaris KAI. 2009. Tree hole utilization by the hairy-eared dwarf lemur (Allocebus trichotis) in Analamazaotra Special Reserve. Folia Primatologica 80: 89-103.

Blom A, Almaši A, Heitkönig IMA, Kpanou JB, Prins HHT. 2001. A survey of the apes in the Dzanga Ndoki National Park, Central African Republic: a comparison between the census and survey methods of estimating the gorilla (Gorilla gorilla gorilla) and chimpanzee (Pan troglodytes) nest group density. African Journal of Ecology 39: 98-105.

Blouin MS. 2003. DNA-based methods for pedigree reconstruction and kinship analysis in natural populations. Trends in Ecology and Evolution 18: 503-511.

Braune P, Schmidt S, Zimmermann E. 2005. Spacing and group coordination in a nocturnal primate, the golden brown mouse lemur (Microcebus ravelobensis): the role of olfactory and acoustic signals. Behavioural Ecology and Sociobiology 58: 587-596. 
Cabin RJ, Mitchell RJ. 2000. To Bonferroni or not to Bonferroni: when and how are the questions. Bulletin of the Ecological Society of America 81: 246-248.

Dytham C. 2003. Choosing and using statistics: a biologist's guide. Malden: Wiley-Blackwell.

Eberle M, Kappeler PM. 2006. Family insurance: kin selection and cooperative breeding in a solitary primate (Microcebus murinus). Behavioural Ecology and Sociobiology 60: 582588.

Elgar MA. 1989. Predator vigilance and group size in mammals and birds: a critical review of the empirical evidence. Biological Reviews. 64: 13-33.

Fan PF, Jiang XL. 2008. Sleeping sites, sleeping trees, and sleep related behaviors of black crested gibbons (Nomascus concolor jingdongensis) at Mt. Wuliang, Central Yunnan, China. American Journal of Primatology 70: 153-160.

Ganzhorn JU. 2003. Habitat description and phenology. Pp. 4056 in: Setchell JM, Curtis DJ, eds, Field and laboratory meth ods in primatology. Cambridge: Cambridge University Press.

Garcia JE, Braza F. 1993. Sleeping sites and lodge trees of the night monkey (Aotus azarae) in Bolivia. International Journal of Primatology 14: 467-477.

Goodman SM, O'Connor S, Langrand O. 1993. A review of predation on lemurs: implications for the evolution of social behavior in small, nocturnal primates. Pp. 51-66 in: Kappeler PM, Ganzhorn JU, eds, Lemur Social Systems and Their Ecological Basis. New York: Plenum Press.

Guo SW, Thomson EA. 1992. Performing the exact test of Hardy-Weinberg proportion for multiple alleles. Biometrics 48 : 361-372.

Guschanski K, Olivieri G, Funk SM, Radespiel U. 2007. MtDNA reveals strong genetic differentiation among geographically isolated populations of the golden brown mouse lemur, Microcebus ravelobensis. Conservation Genetics 8: 809821.

Hamilton III WJ. 1982. Baboon sleeping site preferences and relationships to primate grouping patterns. American Journal of Primatology 3: 41-53.

Hapke A, Eberle M, Zischler H. 2003a. Isolation of new microsatellite markers and application in four species of mouse lemurs (Microcebus sp.). Molecular Ecology Notes 3: 205-208.

Hapke A, Schülke O, Zischler H. 2003b. Microsatellite markers for paternity testing in fork marked lemurs (Phaner furcifer). Molecular Ecology Notes 3: 438-440.

Johnson AE, Knott CD, Pamungkas B, Pasaribu M, Marshall AJ. 2005. A survey of the orangutan (Pongo pygmaeus wurmbii) population in and around Gunung Palung National Park, West Kalimantan, Indonesia based on nest counts. Biological Conservation 121: 495-507.

Kappeler PM. 1997. Intrasexual selection in Mirza coquereli: evidence for scramble competition polygyny in a solitary primate. Behavioural Ecology and Sociobiology 41: 115-127.

Kappeler PM. 1998. Nests, tree holes, and the evolution of primate life histories. American Journal of Primatology 46: 7-33.

Kappeler PM, van Schaik CP. 2002. Evolution of primate social systems. International Journal of Primatology 23: 707-740.

Kappeler PM, Rasoloarison RM, Razafimanantsoa L, Walter L, Roos C. 2005. Morphology, behaviour and molecular evolution of giant mouse lemurs (Mirza spp.) Gray, 1870, with description of a new species. Primate Report 71: 3-26.
Karpanty SM, Wright PC. 2007. Predation on lemurs in the rainforest of Madagascar by multiple predator species: observations and experiments. Pp. 77-99 in: Gursky SL, Nekaris KAI, eds, Primate anti-predator strategies. New York: Springer.

Konovalov DA, Manning C, Henshaw MT. 2004. KINGROUP: a program for pedigree relationship reconstruction and kin group assignments using genetic markers. Molecular Ecology Notes 4: 779-782.

Lahann P. 2008. Habitat utilization of three sympatric cheirogaleid lemur species in a littoral rainforest of southeastern Madagascar. International Journal of Primatology 29: 117134.

Lindenmayer DB, MacGregor C, Welsh A, Donnelly CF, Brown D. 2008. The use of hollows and dreys by the common ringtail possum (Pseudocheirus peregrinus) in different vegetation types. Australian Journal of Zoology 56: 1-11.

Markolf M, Roos C, Kappeler P. 2008. Genetic and demographic consequences of a rapid reduction in population size in a solitary lemur (Mirza coquereli). Open Conservation Biology Journal 2: 21-29.

Moat J, Smith PP. 2007. Atlas of the Vegetation of Madagascar. Kew Royal Botanic Gardens: Kew Publishing.

Müller AE. 1999. Aspects of social life in the fat-tailed dwarf lemur (Cheirogaleus medius): inferences from body weights and trapping data. American Journal of Primatology 49: 265-280.

Nash LT, Harcourt CS. 1986. Social organization of galagos in Kenyan coastal forests: II. Galago garnettii. American Journal of Primatology 10: 357-369.

Nekaris KAI. 2003. Spacing system of the Mysore slender loris (Loris lydekkerianus lydekkerianus). American Journal of Physical Anthropology 121: 86-96.

Nekaris KAI. 2006. Social lives of adult Mysore slender lorises (Loris lydekkerianus lydekkerianus). American Journal of Primatology 68: 1171-1182.

Pages E. 1978. Home range, behaviour and tactile communication in a nocturnal Malagasy lemur Microcebus coquereli. Pp. 171-177 in: Chivers DA, Joysey KA, eds, Recent advances in primatology. London: Academic Press.

Pages E. 1980. Ethoecology of Microcebus coquereli during the dry season. Pp. 97-116 in: Charles-Dominique P, Cooper HM, Hladik A et al., eds, Nocturnal Malagasy primates: ecology physiology and behaviour. New York: Academic Press.

Perret M. 1998. Energetic advantage of nest-sharing in a solitary primate, the lesser mouse lemur (Microcebus murinus). Journal of Mammalogy 79: 1093-1102.

Plumptre AJ, Reynolds V. 1997. Nesting behavior of chimpanzees: implications for censuses. International Journal of Primatology 18: 475-485.

Pullen SL, Bearder SK, Dixson AF. 2000. Preliminary observations on sexual behavior and the mating system in free-ranging lesser galagos (Galago moholi). American Journal of Primatology 51: 79-88.

Queller DC, Goodnight KF. 1989. Estimating relatedness using genetic markers. Evolution 43: 258-275.

Radespiel, U. 2006. Ecological diversity and seasonal adaptations of mouse lemurs (Microcebus spp.). Pp. 211-233 in: Gould L, Sauther ML, eds, Lemurs: Ecology and Adaptation. New York: Springer. 
Radespiel U, Cepok S, Zietemann V, Zimmermann E. 1998. Sex-specific usage patterns of sleeping sites in grey mouse lemurs (Microcebus murinus) in northwestern Madagascar. American Journal of Primatology 46: 77-84.

Radespiel U, Funk SM, Zimmermann E, Bruford MW. 2001. Isolation and characterization of microsatellite loci in the grey mouse lemur (Microcebus murinus) and their amplification in the family Cheirogaleidae. Molecular Ecology Notes 1: 16-18.

Radespiel U, Juric M, Zimmermann E. 2009. Sociogenetic structures, dispersal and the risk of inbreeding in a small nocturnal lemur, the golden brown mouse lemur (Microcebus ravelobensis). Behaviour 146: 607-628.

Rasoloarison RM, Rasolonandrasana BPN, Ganzhorn JU, Goodman SM. 1995. Predation on vertebrates in the Kirindy Forest, western Madagascar. Ecotropica 1: 59-65.

Rasoloharijaona S, Rakotosamimanana B, Randrianambinina B, Zimmermann E. 2003. Pair-specific usage of sleeping sites and their implications for social organization in a nocturnal Malagasy primate, the Milne-Edwards' sportive lemur (Lepilemur edwardsi). American Journal of Physical Anthopology 122: 251-258.

Rendigs A, Radespiel U, Wrogemann D, Zimmermann E. 2003. Relationship between microhabitat structure and distribution of mouse lemurs (Microcebus spp.) in northwestern Madagascar. International Journal of Primatology 24: 4764.

Rode EJ. 2010. Conservation ecology, morphology and reproduction of the nocturnal northern giant mouse lemur Mirza zaza in Sahamalaza National Park, northwestern Madagascar (MSc thesis). Oxford, UK: Oxford Brookes University.

Rode EJ, Nekaris KAI, Schwitzer C, Hoffmann M. 2011. Mirza zaza. IUCN Red List of Threatened Species. <www.iucnredlist.org $>$. Accessed 25 October 2011.

Sambrook J, Fritsch E, Maniatis T. 1989. Molecular cloning: a laboratory manual. Cold Spring Harbor: Cold Spring Harbor Press.

Sarikaya Z, Kappeler PM. 1997. Nest building behavior of Coquerel's dwarf lemur (Mirza coquereli). Primate Report 47: 3-9.

Schmid J. 1998. Tree holes used for resting by gray mouse lemurs (Microcebus murinus) in Madagascar: insulation ca- pacities and energetic consequences. International Journal of Primatology 19: 797-809.

Schwitzer C. 2005. Die Avifauna des Naturschutzgebiets „Sahamalaza-Iles Radama“, Nordwest-Madagaskar. Zeitschrift des Kölner Zoos 48: 133-144.

Schwitzer C, Lork A. 2004. „Projet Sahamalaza-iles Radama”: Ein internationales Schutzprojekt für den Sclater's Maki (Eulemur macaco flavifrons GRAY, 1867). Zeitschrift des Kölner Zoos Heft 2: 47.

Schwitzer N, Randriatahina GH, Kaumanns W, Hoffmeister D, Schwitzer C. 2007. Habitat utilization of blue-eyed black lemurs, Eulemur macaco flavifrons (Gray, 1867), in primary and altered forest fragments. Primate Conservation 22: 7987.

Sterling EJ. 1993. Patterns of range use and social organization in aye-ayes (Daubentonia madagascariensis) on Nosy Mangabe. Pp. 1-9 in: Kappeler PM, Ganzhorn JU, eds, Lemur social systems and their ecological basis. New York: Plenum Press.

Terborgh J, Janson CH. 1986. The socioecology of primate groups. Annual Review of Ecological Systematics 17: 111136.

Thorén S, Quietzsch F, Radespiel U. 2010. Leaf nest use and construction in the golden brown mouse lemur (Microcebus ravelobensis) in the Ankarafantsika National Park. American Journal of Primatology 72: 48-55.

Weidt A, Hagenah N, Randrianambinina B, Radespiel U, Zimmermann E. 2004. Social organization of the golden brown mouse lemur (Microcebus ravelobensis). American Journal of Physical Anthopology 123: 40-51.

Wells K, Lakim MB, Pfeiffer M. 2006. Nest sites of rodents and tree shrews in Borneo. Ecotropica 12: 141-149.

Wright PC, Martin LB. 1995. Predation, pollination and torpor in two nocturnal prosimians: Cheirogaleus major and $\mathrm{Mi}$ crocebus rufus in the rain forest of Madagascar. Pp. 45-60 in: Alterman L, Doyle GA, Izard MK, eds, Creatures of the dark: the nocturnal prosimians. New York: Plenum Press.

Received: 20 August 2012

Revised and accepted: 1 March 2013

Published online: 6 May 2013

Editor: V. Nijman 